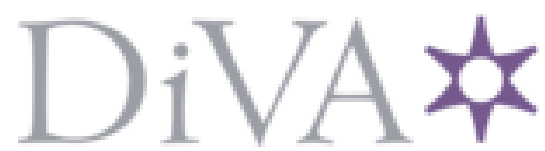

http://www.diva-portal.org

\title{
Preprint
}

This is the submitted version of a chapter published in Theory and Method of Evolutionary Political Economy: A Cyprus Symposium.

Citation for the original published chapter:

Hollander, E. (2017)

The contemporary relevance of Karl Polanyi - a Swedish case.

In: Hardy Hanappi, Savvas Katsikides, Manuel Scholz-Wäckerle (ed.), Theory and Method of Evolutionary Political Economy: A Cyprus Symposium (pp. 54-72). Abingdon: Routledge Routledge Advances in Heterodox Economics

N.B. When citing this work, cite the original published chapter.

Permanent link to this version:

http://urn.kb.se/resolve?urn=urn:nbn:se:hig:diva-23542 


\section{The Contemporary Relevance of Karl Polanyi - a Swedish Case}

Ernst Hollander

(with special support from Maria Malama)

Open-minded social scientists often get surprised when their predictions turn out to be correct. Some are even elated. Elation over accurate predictions, however, can not be expected from present-day scholars inspired by Karl Polanyi (1886-1964). The last 40 years have seen what Karl Polanyi could have called 'disembedding on a global scale'.

The Polanyian concept disembedding focuses on three elements which must be transformed into (fictitious) commodities when attempts are made to create a self-regulating market. ${ }^{1}$ They are: 'Land', 'Labour', and 'Money'. But in the attempts to do so the very web of life is undermined. This is key in Polanyi's analysis (in 1944) of the greatest breakdown in modern civilisation before the one to which we are presently heading. The period leading up to the breakdown of the 1930s - 1940s was called the laissez-faire era.

After the second world war there was widespread scepticism - even in elites - of a renewed attempt to create a self-regulating market. Finance was reembedded and in what we today call the Global North welfare states were created whereby i.a. labour was partially reembedded. In the Global South came a development towards decolonisation and later on attempts to create national economies.

But in the 1970s global finance re-emerged and we entered a neoliberal era which paralleled the laissez-faire era in the overreaching dream of a self-regulating market. In the Global North welfare gains have been reversed, governments have been weakened and labour unions undermined. In the Global South land and water grabbing on a massive scale illustrates the intensified commodification of 'land' in the Polanyian sense.

With the concepts of Rio 92 - we can today talk of the undermining of three categories of sustainability: Economic, Social and Ecological. In spite of great advances in measured GDP and technology many of the dystopian predictions referred to initially have been proven correct.

Among those predictions only two shall be mentioned here. On the financial scene we are watching the most serious crisis since Polanyi's days. And when it comes to right-wing authoritarianism those who already in the 1990s saw the gathering clouds have been far too correct for their own liking.

This chapter relates to the Cyprus conference. The focus there was the crisis in Southern Europe. Here I complement those images by looking at what has happened in Sweden. Together with a number of other countries in Northern Europe Sweden has been viewed as an exemplar in adapting to changes in the world economy. In this it has been contrasted to Southern Europe. Through looking closer at the Swedish case I want to simultaneously illustrate how a Polanyian lens can be used and question the long term resilience of the way in which Sweden has adapted during the last three decades.

\section{Building on Tensions}

Sweden is the largest of the Nordic countries and is outside the Euro zone. We are many who believe that 'a Swedish Model' has been abandoned. When the abandoning took place is more contested. Politico-economic arguments could be given for the early 70s, the period leading up to the Swedish decision in the early 1990s to join the EU, or the ascendance to power of 'the Alliance' in 2006. 'The Alliance' is the right wing coalition which governed Sweden between 2006 and 2014.

The idea that the Swedish welfare state, labour-market, and corporatist model continues to be resilient in the face of challenging global circumstances is, however, also wide-spread. 
In this paper I will methodologically build on a number of tensions. ${ }^{2}$ :

The first tension is the one between an image where a 'Reinvented Model' is applauded and a more critical interpretation of the developments. Early in 2013 the Economist carried a special report called "Northern lights". The subtitle was 'The Nordic countries are reinventing their model of capitalism'. ${ }^{3}$ The rosy pictures represented by the Economist are contrasted to images coming from large parts of the Nordic centre-left where dire socioeconomic tendencies parallel to those in other parts of the West are stressed.

The Economists description is useful for me since it can represent a whole set of analyses which underestimate the risks of disembedding To me the traditional strength of the Nordic Models must be understood in relation to the relative strength of non-elite forces in the developments. Those forces are weakened when there is an over-emphasis on markets as a societal form of coordination.

A second tension is between external and internal forces. The embedded liberalism of the period up to the early 1970 s was dependent on a specific international environment but had deep roots in Swedish history (Blyth 2002). ${ }^{4}$

I also stress a 'Polanyian triangle' which - to my mind - is often neglected by economists. I am referring to the three forms of economic coordination discussed in Polanyi (1957). While Market and Redistribution are discussed a lot, Reciprocity - the oldest form of human coordination for wellbeing - is mostly left to anthropologists. This sad state of affairs is slowly changing in discourses on development economics, social capital etc. But when it comes to mainstream economists' accounts there is still a major dearth. In discussing this triangle I look at a whole family of relations between market and state, NGOs and the state etc. but I refer to them as a third tension.

In this paper I sketch arguments rather than finish them. When trying to think about ways out of 'the Triple Crises' - social, ecological and economic - exercises of such a nature are important. I hope to contribute to a discourse on which Swedish experiences can be used and which ought to be avoided when working for Multidimensional Sustainability. I also want to explore how the reemergence of global finance seems to have undermined even some of the most resilient kinds of embedded liberalism. ${ }^{5}$

\section{Long-term explanations for Swedish Socio-Economic Resilience}

Oft-neglected factors behind the creation and the resilience of 'The Swedish Model' are the wealth of social capital accumulated since at least the mid-19th-century and the protection afforded to the Swedish form of embedded liberalism by 'Bretton Woods' 1944.

Examples of phenomena related to the historical accumulation of social capital are ...

- $\quad$ the old tradition of a strong small-holding peasantry and the weak feudal heritage

plus 19 th and early 20 th century ...

- surge of literacy and basic education

- labour, temperance and other 'popular' movements plus an enlightened bourgeoisie

- $\quad$ independent, movement-based education exemplified by Study Circles, Folk High Schools, Libraries. ${ }^{6}$

Civil Society also had a 'more benign' state to deal with. Rothstein and Trägårdh (Ch. 8 in Trägårdh ed. 2007) stress that the Swedish 19th Century State was less repressive compared to Continental European States. Related to this was extensive local self-government, no legal 
hindrance of unions or strikes, a civil service that was relatively independent and uncorrupt etc. So the Swedish State was rather well integrated with Civil Society. The social formation which evolved has been termed "Democracy from Below".

"... State institutions ... and political processes ..., have played important roles ... [But] equally important is the deliberative and inclusive democratic process that has occurred outside of these ordinary contexts ....".

de Vylder (1996) tries to explain the Swedish success story 1870 - 1960 which was characterised by high growth in GDP and exports, a noteworthy stability etc. He emphasises the "very fortunate combination, or balance, of various forms of capital". Those various forms of course include natural, financial and directly productive capital but also infrastructural and human capital. He specially underlines social capital: "We have norms, institutions, networks, organisations, traditions and attitudes which together constitute a society's social capital."

Yet others stress the massive Swedish emigration around the 1900 turn of the Century. This exodus created a shortage in the labour supply which forced Swedish employers to a more cooperative stance.

After those hints about the historical accumulation of social capital I move on to a more speculative factor for resilience. The idea is that the Swedish Model in a more narrow Economics sense was dependent on the capitals control regime of the early post World War II period. ${ }^{7}$ To political economists the Swedish Model is often focused on the Rehn-Meidner plan presented in the $1950 \mathrm{~s}^{8}$. The idea was that unions, together with the Social Democratic government, should pursue a strategy that simultaneously aimed to equalize wages, reduce inflation, and improve productivity. The union's 'solidarity wage' policy initiated industrial restructuring towards higher-value added economic sectors.

The Model was important historically and could be important in the future. The Model made possible a broader than usual endorsing of international economic transformation and state policies of flexible adjustment. During the first decades after World War II advanced social demands such as that for more just wages could drive industrial restructuring towards economic sectors of the future. Under more benign conditions the mind-set created by the Model could today open for ecologically driven restructuring in accordance with global sustainability needs.

The Model, however, presupposes that that the extra profits which result from the flat solidaristic - wage structure are used to expand firms in the geographic space - Sweden in this case - where those profits are created. In periods of unregulated capital movements such as, laissez-faire before the 1930s or neo-liberalism after the 1970s, the Model will, however, not work. Under such conditions the super-profits of the firms which benefit from the Model will be exported.

The argument is thus that Sweden could continue to build a strong international economic position during important post-war years - that is until around 1970 - with the protection of the Bretton Woods system.

A factor for the relative resilience even after the 'embedded liberalism' had been abandoned is the 'No' to the euro in the 2003 Swedish referendum. Since a wide section of the Swedish elite argued for a 'Yes' this explanation is less discussed in Sweden than one could expect. ${ }^{9}$ 


\section{A First Glance at the Contrasting Images of the Swedish U-Turn}

The Economist's special (2013:3) is applauding that Sweden is a leader in slaughtering sacred cows. "The streets of Stockholm are awash with the blood ...[of sacred cows]".

According to the report the period 1970 - 1990 was a period of decline. Or maybe the decline started already 1960 from whence "the middle way veered left".

The positive trends after 1990 most applauded by the Economist are, i.a., the reduction of public spending as \% of the GDP (from $67 \%$ to $49 \%$ ), the scrapping of taxes on wealth and the cutting of corporate tax rates. Dramatic lowering of real estate taxes - specially for the most wealthy - and Sweden's entry into the race to the bottom of corporate taxes are also saluted.

Some important developments go unmentioned. The dramatic worsening of the Gini coefficient is maybe the most obvious of the omissions. Even OECD reports make it clear that Sweden has had one of the fastest rise in Gini (deterioration in equality) among developed countries in the $1985-2008$ period.

Developments in the educational sector are mentioned but the description is highly biased. Not mentioned is that the Swedish school system which used to provide reasonably equal opportunities and a dramatic reshuffling of Swedish social hierarchies has now turned into a deeply segregated system which is bringing back an ugly class society. One alarming development which might be a result of this is that a high proportion of early school leavers have become authoritarian in their values.

But the Economist's Special (2013:5) is blaming the growing diversity in Sweden rather than the growing inequality. "The growing diversity of Nordic societies is generating social tensions ..." ${ }^{10}$ This is an argument which only the far right is using in Sweden. Up to the end of the autumn 2015 Sweden was - with quantitative measures and on a per capita basis - the most welcoming country in Europe. The growing tensions are in my analysis resulting from such factors as rising unemployment, dismantling of strong labour rights and a general weakening of social cohesion - not growing diversity per se.

\section{Squeezing or challenging business?}

In order to understand the contrasting images it is useful to look at both the economy at large and at specific sectors / companies.

According to the Economist's Special "the new Nordic model begins with ... fiscal responsibility rather than pump-priming" (2013:4). In fact a hallmark of the Rehn/Meidner Model was that it aimed at stemming inflationary tendencies by combining restrictive fiscal policies with supply side measures such as subsidies for retraining, resettling etc. It was decidedly anti-cyclical. 'The model' was successful until the fall of the Bretton Woods system. The irresponsible fiscal policies of Sweden which eventually brought about a major crisis in the early 1990s were in fact initiated by the right wing parties during their 1976 1982 reign(Blyth 2002: 219-220).

Another part of the Economist Special's analysis of the fall of 'the old model' is that "the Social Democrats ... kept squeezing business". To my mind this 'squeezing' posed healthy challenges to the elites. And challenges came from all kinds of non-elite forces. Solidaristic policies of 'the Model' were definitely problematic for unproductive firms in industries such as textiles. The concomitant demands for better work environments - both physical and psycho-social - were challenging for engineers and production designers who had to listen 
simultaneously to worker and productivity demands. Demands for less toxic environments were also challenging (Hollander 2003). All those challenges became seeds of innovation.

Also at the company level I would argue that 'the old Model' had many benign effects. This can be can be illustrated with the very innovations mentioned in the Special Report. Those innovations can be traced to the environment created by 'the Model'. Some examples: The strong position which Ericsson continues to have has important roots in the historic cooperation with the Swedish Telecom Board which was still state owned at the time when the basis was laid for Ericsson's present position as leader in telecom equipment. The telecom board was a sophisticated demand shaper. ${ }^{11}$

Likewise the strength of Volvo Trucks has a lot to do with traits of 'the old model'. Strong work environment demands were important when Volvo Trucks developed its leading edge in global markets.

The Special Report stresses Sandvik's obsession with promoting productivity'. Maybe it would be useful to ponder the role of a strong and constructive Metal Workers' Union when looking for the roots of this.

The Special Report states that "the compression of Swedish incomes ... almost killed the goose that laid the golden eggs". With this statement we come to the core of the controversy. We who appreciate the legacies can quite to the contrary think that for instance the advanced production systems which are the envy of so many engineers around the globe can be seen in relation to the solidarity wages policy which was a corner stone of the old model (Sandberg 2013 i.a. chapters 2 and 5).

The root causes of the disintegration of the Nordic models should rather be looked for in international developments. The Swedish 'success story' 1860 - 1960 included a balanced adaption to the international environment and openness to trade. The companies - some of them mentioned above - which still dominate the Swedish economy tried their wings early on in international competition.

The Bretton Woods architecture reopened world trade after World War II. Swedish companies early on invested abroad in production capacity. What changed when Bretton Woods 'ended' was that Swedish big firms gradually got more choice of whether to adapt to internal Swedish challenges or focus more on expanding abroad. Earlier they could be counted on to pursue both those strategies simultaneously.

In the 1970s the international conditions for the model were thus changing dramatically. The real choice was already then between dismantling or developing the Model.

Among 'sectors' where there were attempts to develop rather than dismantle one can underline gender equality, ecological sustainability and work-place codetermination. To paraphrase the Economist's Special the Swedish centre-left consciously tried to make Swedish companies and other institutions " ... reach the future first". ${ }^{12}$ Results in the three areas mentioned and in many others were impressive. 


\section{The Logic behind the abandoning of the "Post War Swedish Model"}

If we discard the idea that 'the old' Swedish Model of 'embedded liberalism' was economically unsustainable - how can we understand that it was dismantled? And what was the role of Social Democracy in this?

We need to start in 'the Polanyian Period' in order to understand the dramatic change away from the Swedish socio-economic formation that seemed so attractive to 'centre-left' observers 40 years ago. ${ }^{13}$

We single out five periods of importance for the story and start with the interwar period after the $1^{\text {st }}$ World War. Taking 'a central European perspective Polanyi referred - in an article from 1933 - to the time span ranging all the way back to 1918 as 'one single economic crisis' (Polanyi [1933; 1999]: Ch. 31).

In Sweden the long period of uninterrupted Social Democratic domination of Swedish politics started in 1932. Initially it built on a class alliance between workers and peasants' and a labour movement compromise with the leading factions of capital. Those 'internal' compromises made possible continued economic growth and prevented fascist forces from gaining strength. The ideological basis for the crisis policies of the 1930s has by Ryner been described in terms of

"a Marxist-institutionalist synthesis represented by the coming together of the thought of Marxist-inspired activists ... and Ernst Wigforss on the one hand and Gunnar Myrdal on the other. ..."14

Sweden then entered the post- $2^{\text {nd }}$ World War period with a more or less intact production system. The period up till the mid sixties -is the second period we consider. It was partly the booming early post-war years which formed the frame when the 'old Model' was conceived. The first seeds of the coming demise of the model were, however, sawn already during this period. The centralisation of wage bargaining was a prerequisite for labour's ability to deliver on its promises in negotiations. But a tendential fall in mobilisation of the labour movement was at the same time a threat to its cohesion and creativity.

Swedish democratic modernity - much admired at the time - has also been accused of developing an insensitivity. The million dwelling units program $(1965-1975)$ has been quoted as the case in point. This program was developed as an answer to a housing crises in big cities following the 'structural rationalisation' of the 1950's. The program and the spirit which it represented is still contested.

As in the rest of the Global North the year 1968 is a symbol for a youth uprising in Sweden. Our third period stretches from 1965 to 1982 and thus includes the period of the first centreright government since 1932. In my tradition the '1968 uprisings' are seen as 'generated by contradictions of Fordism'. The tensions had the double effect of shaping on the one hand a 'Swedish New Left' within and outside Swedish Social Democracy and on the other a dawning Swedish Neo-Liberalism.

The centre-right government's fiscal irresponsibility and parody of industrial policy in the late 1970s further delegitimised 'the Swedish Model' in spite of the fact that those policies were pursued by centre-right governments. When the Social Democrats (SAP) returned to political power its political ambitions had changed compared to those of the early 1970s (Östberg 2012).

The centre of gravity in the Swedish state and in the labour movement had changed in our fourth period - from 1982 to 1994. Economic state managers wielded more power than 
hitherto and the policy pursued by the Social Democratic governments was 'compensatory neo-liberalism' according to left critics.

In the fourth period Sweden was made wide open for International Financial Capital. The short term background included a 'run on the Swedish Krona (SEK)' and the SAP government abandoning the unconditional full employment commitment as well as announcing its intention to apply for EC membership (Lindberg \& Ryner 2010:36).

Before discussing our fifth period (1994-2014) we ought to point to definitions of commodification and financialisation. Since this is discussed elsewhere in the book we just cut from the FESSUD project - see below. According to FESSUD on Sweden (2014:16) ...

$"$ "... the processes of financialisation contain ... de-regulation of the financial system itself and the economy more generally; ... at a systemic level, the dominance of finance over industry, ..."

(Re-) commodification means that for instance social services are commodified. This is a prerequisite for financialisation.

We will split the fifth period into 5a and 5b. During 5a the (re-) commodification and financialisation of central societal areas, were introduced on a tentative yet fateful scale. The areas include housing, as well as Health, Child care, Schooling, Care for the elderly - for short "HEW". 15

The pension reform of the late 1990s also represented a paradigmatic shift to neo-liberalism (Belfrage \& Ryner 2009).

Cynically period 5 in its entirety can be viewed as a time of preparation for, and realisation of, massive 'venture capital' private profits in central societal areas. The "HEW" part of this process has been described in a book which will be used below as one starting point in a section which contrasts two images of Swedish (re)commodification / financialisation.

Period 5b - 2006-2014 - when a centre-right governments led by Reinfeldt ruled - meant concerted efforts to undermine foundations of the socioeconomic formation built by the Social Democrats (SAP) from the 1930s to the 1970s. This formation of the 1930s to the 1970s has been described by Social Democrat economists as resting on four pillars (Carlén, S. et.al. 2014: 29-33).

a) Labour market characterised by high degree of unionization, sophisticated partners and 'self regulation of the labour market' by those partners.

b) Social insurance compensations covering a high percentage of the income before the time of the damage. The social insurance financed by levies proportional to income.

c) Central welfare services ('HEW') paid by taxes and conducted by public authorities. The services distributed according to need and provided on equal terms to all citizens.

d) Taxes high enough to finance advanced public ambitions combined with a tax system which was per se redistributing.

This run-through of 'the pillars' is very rough. But I now turn to 'the attacks' effected by the Reinfeldt government. Briefly summarised (Carlén, S. et.al. 2014:208-212):

Attack on pillar a - Labour market)

Rebalancing the Labour market in favour of the employers through making union membership as well as unemployment insurance much more expensive.

At the same time institutional reforms were passed which favoured employers in low wage service sectors. 
Attack on pillar b - the Social insurance system)

Drastic reductions in rate of income guarantee also in the other social insurances sick leave, parental leave etc. Less support for rehabilitation after hardships and for moving to other jobs.

Growing subsidies etc. for private insurance solutions.

Attack on pillar c - the 'HEW system')

Marketization, privatisation and financialisation of the Swedish HEW system.

Attack on pillar d - the Progressive tax system)

General lowering of taxes. Weaker redistributive effect of taxes. Massive subsidies to

low wage service sector making life easier for the wealthy.

An even bigger problem than the roughness of this run-through is that it is based on an account which puts all the 'blame' on the policies pursued during $2006-2014$. The dismantling effected or prepared earlier is then underrated. Therefore the next section will contrast two accounts which have longer time perspectives. Before that, however, a paragraph on 'the end of 'period 5'.

The results of the Swedish election in September 2014 meant an affirmation of Sweden having turned into a 'normal' European country. A Social Democratic - Greens government has been formed. If we, however, count the so called Sweden Democrats - which gained almost $13 \%$ of the votes - as being a party of the extreme right we see that right wing in Sweden has achieved the upper hand in the Parliament in the present decade (from 2010). The advantage is now 10 percentage points. Since the 1930's there has only been one decade before when the right wing had the upper hand and that was in the 1970s and it then had it by only a few percentage points (Bengtsson 2014).

\section{Contrasting Images of Commodification / Financialisation}

I will start the contrasting with a portion heavily influenced by a book, the title of which echoes Polanyi's most famous one. In English the title could be The great transformation The Welfare Market Scrutinized. ${ }^{16}$

After that portion comes one heavily influenced by a study which views Swedish financialisation with more sympathetic eyes.

\section{A 'great transformation' of the provision of Swedish ' $H E W$ '}

In “... - The Welfare Market Scrutinized” Werne et.al. describe 'the financialisation of

Swedish HEW'. From my point of view the most serious consequence of this 'great transformation' is that cohesive forces such as solidarity, voice, idealistic entrepreneurship etc. have been undermined. This can also be phrased using the Polanyian concept 'reciprocity'. We could call it 'forced reduction of reciprocity'. Below I use the phrase social capital depreciation.

A case in point is the Swedish version of the Friedmanian 'voucher plan' for schools - the 'Skolpeng'. ${ }^{17}$ When studying the consequences of the introduction of 'skolpeng' and related developments Verdinelli looked i.a. at internet discussion threads dealing with how parents themselves decide how to choose schools for their kids.

'Ethnic Swedish' parents shy away from schools in 'immigrant dense' areas. The concept 'immigrant dense' is, however, in fact a signifier of an 'unfavourable class composition' in an area. Even though you - as a citizen - might be in favour of the old type of mixed schools you - as a parent - feel guilty if you don not choose 'the best' for your kids. And 'the best' has to 
do with the networks you help your kids to get in to (Verdinelli's Ch. pp. 173-196 in Werne and Unsgaard ed. 2014).

Sweden can thus be said to be a front-runner in in extending the number of Polanyian fictitious commodities. Polanyi's traditional list of three fictitious commodities should maybe be extended with three semi-fictitious commodities: health, education and welfare According to Werne et.al. the financialised part of the Swedish HEW sector was in 2012 above $1 / 6$ of the total sector value. The commodified part - run according to the logic of price competition - is, however, much bigger since the private part of the sector exerts a strong influence on the publicly provided. And it is all financed by tax payers' money.

The commodification/financialisation can be traced back to the 1970's - the third period discussed above - when Swedish neo-liberals first sketched a counter-attack against what was perceived as a Swedish way to serfdom. ${ }^{18}$ After a while the counter-attack got a strong backing from the Swedish employers' association and in 1992 Sweden became the pioneer in real-life use of the Friedmanian 'voucher plan' for schools.

An important aspect of Sweden becoming a front-runner in financialisation of HEW was the weak resistance from Swedish Social Democracy. Among the explanations suggested was the widespread criticism - also on the 'left' - of the standardised methods applied when for example education went through a thorough-going expansion and modernisation from the 1960s onwards. The reluctance from municipal authorities to accept, let alone encourage, experiments with new pedagogic ideas à la Montessori or Freire etc. are cases in point.

Some important early moves in the direction of commodification/financialisation of HEW were taken by a centre-right government in the early 1990s. But when the Social Democrats returned to power in 1994 the forces for continuing in the HEW financialisation direction were already rather entrenched - also within parts of Social Democracy.

With historical hindsight the arguments used for introducing capitalist competition into the provision of schooling were rather insidious. The kind of schools which were to be given a (second) chance were such as parents' coops, remote area village schools threatened by closure, schools specialised for 'niche' subjects etc.

After 'consolidation' of the private HEW sectors in the first decade of the $21^{\text {st }}$ century the markets were, however, dominated by a few huge corporations often domiciled in tax havens. The idealists of the 1980s didn't stand any chances when confronted with giants who could profit from i.a.

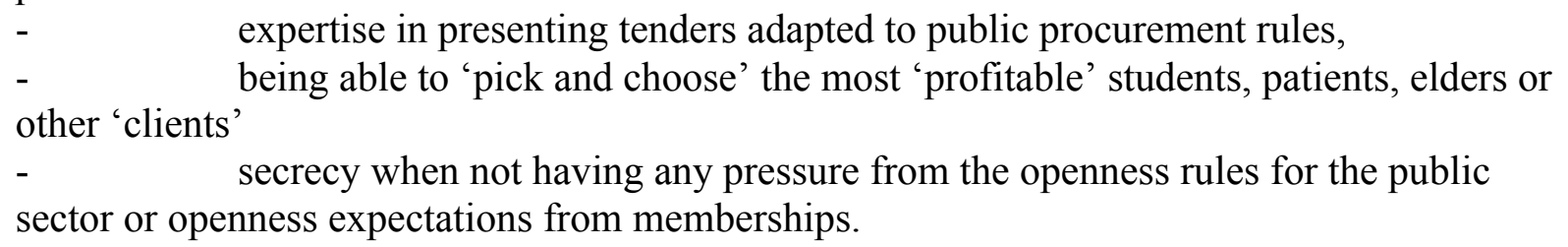

In 2011 the business-sponsored think-tank SNS published an evaluation of the introduction of competition in the HEW sectors. Translated the title could be The consequences of Competition - What's happening to Swedish Welfare and was written by a group of highly regarded researchers (Hartman (ed.) 2011).

In a chapter on education the researcher mentions the risk that the actors will base their choice of schools on criteria such as 'generosity' in the grading of students, 'feel-good'-factors, the 
socio-economic composition of the parents etc. In another chapter - on eldercare - a tentative conclusion is that competition has led to deterioration of quality in both the public and private parts of the sector. Both parts of the sector now focus on lowering prices through reducing costs.

The editor of the report - Hartman - resigned from the think tank SNS when she wasn't allowed to answer critique from the 'HEW financialisation lobby'. Since SNS was hitherto considered to be reasonably independent, a heated debate ensued after the resignation.

Commodification/ financialisation of HEW remains a 'contested terrain' in Sweden. The public sentiment at this field has been changing. Mistrust against the public sector was common in the early 1990s. But in 2012, when asked about the idea to limit profits in the welfare sector most of the respondents were in favour. When answering a survey in 2012 altogether $62 \%$ considered it a good idea (42\% strongly in favour, $20 \%$ in favour). Part of the background to the shift in public opinion was a number of scandals associated to large private risk capital HEW companies.

\section{"The Ideal Country for Financialisation"}

The phrase 'ideal country for financialisation' is from Stenfors (2014:15). I can partially agree with this description of Sweden but not with Stenfors' arguments for it. I might more sadly call Sweden between the 1970s and now: 'The 'ideal country for social capital depreciation'.

My aim when using Stenfors (2014) is to show what you might see when viewing Swedish financialisation with sympathetic eyes. First a quote from his executive summary: "... the ... transformation of ... Swedish society ... that began in the 1980 s ... can be summarised as follows:

First- ...

Fourth, neoliberalism (as defined broadly) has penetrated the Swedish society profoundly, ... the country has transformed itself from a role model for those wishing to implement reforms often associated with [Swedish Social Democracy] to a 'poster boy' for European parties on the Right

...

Seventh, the financialisation process has become highly visible in overall 'daily life', not least as market mechanisms have been encouraged to enter previously 'sacred' areas, such as housing, education, health care and pensions." (Stenfors 2014:10-12)

Many of the features share traits with the pension reforms that turned "working population (past, present and future) into investors and risk managers".

On the new pension system itself Stenfors says i.a.: indirectly."

"Seen in comparison to the Swedish GDP, stock market turnover rapidly increased from less than $8 \%$ to over $200 \%$ (before the outbreak of the global financial crisis)." (Stenfors 2014:155, 128 and 29-30)

The financialisation of everyday life is also intensively sensed by all Swedes: A Swedish author reflects:

"The apartments in the house where I live are turned into individual private property. In the private school a lower proportion of the kids drop out. 
... Shall I then sacrifice myself? My son? My home? Of course not. And thus we all become parts of a system which we have not chosen ourselves - into which we have been forced" (Lundberg 2013:14)

Swedes thus feel forced away from solidarity 'at gunpoint'. Returning to an academic socioeconomic language I quote from Stenfors' summary of Clark \& Johnson (2009):

"structural changes in housing policies in the 1990s had significant consequences in a range of areas: a decline in new construction and a rise in vacancies; an increase [in] crowded housing conditions; an increase in privatisation and outsourcing of housing planning; an increasing segmentation in terms of gaps between different forms of tenure; the closing of municipal housing agencies and the abandonment of social housing commitments; ... and a social polarisation manifested in growing 'supergentrification' and low-income filtering., 19

The structural changes in housing policies combined with lowered ambitions regarding balanced regional growth had foreseeable effects on real estate price developments. Falling prices in peripheral areas and sky-rocketing prices in the centre. For instance real estate price index for one- or two-dwelling buildings for permanent living in the three largest urban areas in Sweden rose from 100 in the early 1980s to between 700 and 800 in the second decade of the $21^{\text {st }}$ century.

A precondition for financialisation is what Stenfors refers to as 'Market-oriented Reforms'.

"During the last few decades, a range of industries and services have been opened up to competition, either through direct privatisation of state-owned companies, or by allowing profit-maximising companies to enter the market. ... with regards to areas such as taxi, mail, childcare and education, Sweden could be regarded as a 'frontrunner'...

Other remarkable aspects of the Swedish financialisation process are less visible to all Swedes.

"... Within the international foreign exchange markets, Sweden has evolved from being perceived as a volatile, unpredictable country during the late 1980s and early 1990s to gradually gaining a 'safe-haven' status (Stenfors 2014:88 and 11).

A very important development - in fact a cornerstone in the global transformation to financialised capitalism - is also very noteworthy in Sweden. ${ }^{20} \mathrm{I}$ am referring to a development where also non-financial corporations derive more and more of their incomes from financial activities.:

"throughout the period [1995-2011], property income ... has increased significantly as a share of total resources ... This trend has been driven by an increase in dividend payments and other financial incomes obtained by non-financial corporations, ... The high proportion of property income obtained by Swedish non-financial corporations is fairly high compared to other countries (Stenfors 2014:10).

Before ending this portion it is reasonable to give an account of some of the points where I diverge from Stenfors' (sometimes implicit) analysis. This task is made easier since there are important similarities between the way in which 'the old Swedish Model' was understood in The Economist's Special (2013)from 2013 discussed above and the way in which Stenfors implicitly interprets the old Model. For instance; when Stenfors claims that ...

... 'the Rehn-Meidner model could ... be seen as a 'third way' - by rejecting monetarism and questioning Keynesianism' ... (Stenfors 2014:131) 
... he is ahistorical since monetarism was not around when the Rehn-Meidner model was conceived. But more importantly the Rehn-Meidner model should to my mind be seen as a development of Keynesianism through combining it with a Marxist legacy. This development of Keynesianism was possible partly because of the strength of the Swedish union movement. Just as the 'old model' had nothing to do with 'pump-priming' it also in no way was something in between Monetarism and Keynesianism.

More generally I miss 'agency' in Stenfors' account. The victories of the Swedish Model in the early post $2^{\text {nd }}$ World War years were certainly partially fruits of historical legacies from way back. But they were also fruits of a very astute strategy developed by Social Democracy during the first half of the $20^{\text {th }}$ century. And when the model was abandoned from the $1970 \mathrm{~s}$ onwards it was certainly a consequence of international developments such as the fall of the Bretton Woods system. But as I see it, it was also due to conscious and semi-conscious actions by those opposed to the gradual transformation of Sweden into less of a class society. To me the economic and industrial policies 1976-1982 amounted to semi-conscious undermining of the model. Blyth (2002 i.a. in Ch. 7) has argued forcefully for agency. Moving closer to today the weakening of unions 2006-2014 was definitely conscious. Two more critical points concerning Stenfors' analysis shall be briefly mentioned:

- $\quad$ The very significant developments surrounding the Swedish financial crises and the Swedish application for membership in the EEC/EU in the early 1990s are hardly discussed at all.

- When discussing HEW commodification Stenfors again dodges away from the politics of the developments. He writes about how the public sector has developed from 'an instrument of social transformation' to a kind of neutral service producer:

"A number of market-oriented reforms have been passed in order to increase efficiency in the public sector by allowing private initiatives to operate in parallel" (Stenfors 2014:89).

To my mind the changes made are just as much instruments of social transformations. But of course with other political aims.

My criticisms, however, does not change the fact that the FESSUD project has done a great service to economics by supporting Stenfors in providing a uniquely comprehensive overview of a remarkable example of financialisation.

\section{Finding Contours of the next great transformation}

- Are there still Lessons to be learned from Northern Legacies of Reciprocity and Redistribution?

The header for my final section of this chapter is replicating the name of the Cyprus Symposium Special Session on Polanyi as well as the contribution on which this chapter is built.

Here I will use the Swedish case to discuss the 'contemporary relevance of Karl Polanyi' using concepts introduced earlier in the chapter. After that I'll exemplify how the reduction of Reciprocity and Redistribution might have undermined the Swedish Model but also whether there are still resilient features of the model which might be useful for the future. Finally I will point to three examples of ideas which can help us continue to hope in spite of all the lessons not to be learned from the many 'detours' of the last 40 years.

\section{Contemporary Relevance}

The Swedish case underlines the centrality of finance. The financial policy changes of the late 1980s are central if you want to understand 'the Swedish U-turn'. Polanyi and the many- 
faceted research community inspired by his works are rare in the 'sustainability sciences' in clearly identifying the economic sphere as central for the dangers of humanities' present course. Polanyi's analysis of fictitious commodities made clear that it is the very web of life that is at stake when money is converted into a (fictitious) commodity. ${ }^{21}$

The Swedish case is also specially poignant in calling forth the idea that Polanyi's list of fictitious commodities might have to be extended. This is because the financialisation of Swedish HEW has been so dramatic.

A key lesson from Polanyi's Great Transformation is that the counter movements unleashed by laissez-faire (or today's counterpart neoliberalism) might come from the right wing populists or even fascists. 40 years ago there were few social scientists who saw the risks of right wing populists in a country like Sweden. Today the Swedish populist right party 'The Sweden Democrats' has according to reliable surveys won $\approx 20 \%$ of the electoral support (up from $\approx 3 \%$ in the parliament election 2006 and $\approx 13 \%$ in the parliament election 2014) and an MP of the party has gotten away with instigating mass acts of arson against buildings planned to be converted to house refugees. ${ }^{22}$

As suggested above ( $3 \mathrm{~d}$ tension) the concept reciprocity points to yet another 'blind spot' - at least in important parts of the social science community. The importance and future relevance of reciprocity therefore remains 'under-explored'. But happily there are now - even among prominent economists - dissenting voices who suggest a 'coming age of reciprocity'.

'Community governance' can serve as a description not only of 'peripheral' or traditional modes of cooperation but also of evolving patterns of the future. ${ }^{23}$

The Swedish case can nurture this idea that reciprocity - seriously suppressed during modernity - will re-emerge as an important principle.

\section{Resilient features}

This brings me over to some resilient features with roots in developments from the 1930s to the 1970s. Above I pointed to gender equality, ecological sustainability and work-place codetermination as areas where there were attempts to develop rather than dismantle 'the old Model'. More generally I suggest that the traditions of "Democracy from Below", transparency, reciprocity and equality can be revived and actually still show their promising faces at many occasions. Many innovations on which Sweden still builds much of its material fortunes are, as I argued above, a heritage from the times when there was more room than today for constructively challenging the elites.

\section{Contours}

The very era which the Economist calls a 'period of decline' $(\approx 1965-1990)$ can actually be seen as one when some seeds of a coming great transformation were first nurtured. Better gender equality has resulted in social innovations which can facilitate a balance not only between the genders but also between different spheres of life. A case in point is that the parental leave insurance system encourages sharing the care of children. Work-place codetermination laws can very well have paved the way for less cumbersome transitions to more horizontal ways of working together. One attire in which reciprocity might reemerge on a societal scale might thus be as peer-to-peer-production. And readiness to embrace ecological sustainability has opened up for lots of innovations.

The example of ecological sustainability as one harbinger leads over to three very different books relevant for reflections on a 'possible Swedish / Nordic contribution' to finding contours of the next great transformation':

The 2016 yearbook of the Swedish Society for Nature Conservation has the theme 'Ägodela köp mindre, ...'; in English something like 'OwnShare - Buy less, get access to more' (SNF 
2016). The book features non-commercial examples of the sharing economy in fields such as mobility, housing, clothing food etc. The social and material innovations point - at a practical level - far beyond our present society.

At a more systemic level Eric Helleiner is also visionary in his 20 year old idea of reembedding at many levels (Helleiner 1995). Above I reminded that 'Bretton Woods' created a partial reembedding of global finance. I suggested that the environment created thereby was important for the Swedish Post $2^{\text {nd }}$ WW Model. ${ }^{24}$ There were similar experiences in the other Nordic countries. When trying to revive "Democracy from Below", but now on a global scale, the idea of multi-layered reembedding ought to be considered. Then the Nordic experiences could be useful.

Finally; some ideas from Paul Mason's recent book could suggest that Sweden might be well prepared for the networked postcapitalist society he envisions. Swedish ICT-density is very high, collaborative work-patterns reasonably frequent and the academic and other white-collar unions better organised than elsewhere. According to Mason we might learn a lot about the future by looking at Wikipedia which is organised "in a decentralized and collaborative way, utilizing neither the market nor management hierarchy." ${ }^{25}$ So; there might still be a few things to learn from Sweden's long history of reciprocity on the tortuous 'road to Freedom'.

\section{Notes}

${ }^{1}$ I often use italics to signal that a certain concept is fetched from a discourse which I don't have the space to explain. At some instances I provide concept-explaining ref's in this text. I am of course happy to communicate with readers about concepts which remain unclarified here. /EH

2 'Building on tensions' is a 'signifier' of some of my methodological convictions. One account of those can be found in Hollander (2011) pp. 14-23./EH.

${ }^{3}$ Henceforth referred to as Economist's Special (2013).

4 This note on references has to do i.a. with my Swedish '1968' background. Sweden is 'a small country' and many with '1968' backgrounds' know each other. Specially if we consider those of us who aspired to be movement intellectuals of the diverse set of 1968 red-green movements. Even so we are too numerous for me to give 'due cred' to even a fraction of those whose accounts - written or verbal - inspired my image of the rise, fall and lessons from the 'Swedish Model'. And a lot of inspiration also comes from persons who do not have a '1968' background. Disregarding backgrounds quite a few inspirators go unmentioned here. Some can be found in references in the works of authors who I do refer to in my text. A case in point is Blyth (2002). Other examples of overviews are Ryner (several years), Sandberg (ed.) (2013) etc. An author who also provides an overview but who goes unmentioned in my text except here is Hort (2014).

Besides those who I directly or indirectly refer to I - below - provide a list of names that you as a reader can 'google' (for instance use the intersection of one of the $<$ names $>$ and $<$ Swedish (or Nordic) (Welfare) Model>. One criteria for inclusion is that their texts are available in English. Another is that they cover areas where there is a special dearth in my own text. None of those principles are followed consistently:

Klas Åmark, Irene Wennemo, Asbjørn Wahl, Claudius Riegler (mainly in German), Victor Pestoff, Rudolf Meidner (at least one book co-authored with Anna Hedborg), Andrew Martin, Rianne Mahon, Kurt Lundgren, Staffan I. Lindberg, Andrew Jamison, Annika Härenstam, Kaj Frick, Christian Berggren, Lars Bengtsson, Gösta Esping Andersen. 5 The phrase reemergence of global finance is inspired by Helleiner (1994). 
${ }^{6}$ Sources for this 'intro to Swedish historical accumulation of social capital' include: Trägårdh (Ed.) (2007) and de Vylder (1996).

7 The capitals control regime of the early post World War II period is discussed i.a. in Helleiner (94) and (95).

8 See Erixon (2010), Haley \& Hollander (2006) and Hollander (2011) as well as references there.

${ }^{9}$ Concerning the 'wide section of the Swedish elite' see Ingebritsen (1998) pp. $143 \mathrm{ff}$. 10 The Economist's Special (2013:5).

11 The concept demand shaper is presented in Hollander (2003). There you also find more examples of innovations nurtured by sophisticated demands.

12 The phrase 'economic sectors of the future' connects to the Economist's Special. According to the report '... the Nordic countries have reached the future first'.

${ }^{13}$ When I talk about 'the Polanyian Period' it is based on the idea - mentioned above that there are important parallels between the disembedding effected by the laissezfaire policies of the century leading up to WW I and those effected by the neo-liberal policy period from $\approx 1975$. 'The Polanyian Period' also includes the period from 19181939 when all kinds of countermovements - left and right, democratic and authoritarian - emerged. Polanyi wrote The great transformation in 1944. I got inspiration for talking of a 'Polanyian Period' and for exploring the parallels from Helleiner (1995).

${ }^{14}$ Ryner (2004) p. 13. Also the following account is built a lot on Ryner (several years).

15 Concerning the phrase 'Health, Child care, Schooling, Care for the elderly' I will henceforth sometimes use the US acronym HEW (health, education and welfare). There are, of course, many differences in Swedish <-> Anglo 'welfare systems' but I will not go into those here.

16 Werne and Unsgaard ed. (2014). Polanyi's book is (Polanyi 1944).

17 See Friedman (x2) (1979) for the original Friedmanian plan.

18 The 'way to serfdom' refers to Hayek's term. Swedish neo-liberals, were worried about a 'Swedish way to serfdom' and studied Hayek and his follower Milton Friedman intensively.

${ }^{19}$ Stenfors (2014:114) summarising Clark \& Johnson (2009).

20 On the 'global transformation to financialised capitalism' see (Orhangazi 2008).

${ }^{21}$ See the intro to this chapter as well as Hollander et.al. (2015).

22 That a Polanyian framework might predict such a surge in right wing populism was mentioned also in the introduction. Such a prediction could also be reached by an entirely different - quantitative - approach. This was recently demonstrated by Funke et.al. (2015).

${ }^{23}$ See my interpretations of some prominent economists in Hermele \& Hollander (2008: 7-8).

${ }^{24}$ A special thanks to Gary Dymski for encouraged me to explore this aspect of the Swedish history.

${ }^{25}$ Mason (2015) i.a. Ch. 5. Ideas related to the concept peer-to-peer-production are presented there.

\section{References}

Belfrage, C. and Ryner, M. (2009) 'Renegotiating the Swedish Social Democratic Settlement - From Pension Fund Socialism to Neoliberalization' Politics \& Society 37: 257-287.

Bengtsson H. (2014), Arena \#5 pp. 17-18, Stockholm. 
Blyth, M. (2002) Great Transformations: Economic Ideas and Institutional Change in the Twentieth Century, Cambridge: Cambridge University Press.

Carlén, S., Persson, C. and Suhonen, D. (2014) Reinfeldtkoden - ... (In Swedish) Stockholm: Ordfront.

Clark, E. \& Johnson, K. (2009) Circumventing circumscribed neoliberalism: The system switch in Swedish housing. In: Glynn, S. (ed.) Where the other half lives - Lower income housing in a neoliberal world, London: Pluto 173-94.

de Vylder, S. (1996) 'The Rise and Fall of the Swedish Model', UNDP Occasional Paper No. 26.

The Economist's Special report (2013) 'Northern lights - The Nordic countries are reinventing their model of capitalism' The Economist February 2nd, London.

Erixon, L. (2010) 'The Rehn-Meidner Model in Sweden - Its Rise, Challenges and Survival' Journal of Economic Issues 44(3) March pp. 677-715.

FESSUD on Sweden (2014). FESSUD Studies on Financial Systems, No 13 - The Swedish Financial System. By Alexis Stenfors. The study was placed on the FESSUD website in 2014. It is available via http://fessud.eu/deliverables/

This study I sometimes call "Stenfors (2014)" and sometimes "FESSUD on Sweden (2014)".

Friedman, M. and R. (1979) 'Free to Choose - A Personal Statement' New York: Harcourt.

Funke, M., Schularick, M. and Trebesch, C., (2015) 'Going to Extremes: Politics after Financial Crises, 1870-2014', CEPR Discussion Paper No. DP10884, Munich.

Haley, B. \& Hollander E. (2006) 'Advanced Sustainability Demands from Labour -Reembedding for Democracy and Ecology', Unpublished manuscript for a book that was supposed to be published by the CITA of the U. of Mass. at Lowell (UML). Book not published but the manuscript is available from me. / EH.

Hartman, L. (ed.) (2011) Konkurrensens konsekvenser - Vad händer med svensk välfärd? (In English this would be $\approx$ The consequences of Competition - What's happening to Swedish Welfare) Stockholm: SNS Förlag.

Helleiner, E., (1994) States and the Reemergence of Global Finance, Ithaca: Cornell University Press.

Helleiner, E., (1995) 'Great Transformations: A Polanyian Perspective on the Contemporary Global Financial Order' Studies in Political Economy (SPE) No. 48 Ottawa pp. 149-164.

Helleiner, E., (1999) 'Globalization and Haute Finance - Déja vu?' in: McRobbie \& Polanyi Levitt (eds.) Ch. 2 pp. $12-31$.

Hermele, K. \& Hollander, E., (2008) 'Taking sustainability into account' Full manuscript for paper later published in VHU (2008): Frostell, B., et.al. (eds.) Science for Sustainable 
Development - The Social Challenge with Emphasis on the Conditions for Change. VHU, Uppsala. The full manuscript is available from me. / EH.

Hollander, E., Hermele, K., Negru, I. and Dymski G. (2015) 'Using Polanyian concepts to bring together sustainability discourses' Special session at the 11th ESEE conference in Leeds

Hollander, E., (2011) The Doll, the Globe and the Boomerang: Chemical Risks in the Future - Introduced by a Chinese Doll Coming to Sweden Research Report 2, University of Gävle.

- (2003) 'The noble art of demand shaping - how the tenacity of sustainable innovation can be explained by it being radical in a new sense', Contribution to 11th international GIN (GIN $=$ Greening of Industry Network), conference in San Francisco. The contribution not published but is available from me. / EH.

Hort (f.d. Olsson), S, E O (2014) Social Policy, Welfare State, and Civil Society in Sweden, Volume II: 'The Lost World of Social Democracy 1988-2015', Lund: Arkiv.

Ingebritsen, C. (1998) The Nordic States and European Unity Ithaca: Cornell University Press.

Lindberg, I. \& Ryner, M. (2010) 'Financial Crises and Organized Labour - Sweden 1990 to 94' International Journal of Labour Research (ILO journal), Vol. 2, No. 1, pp. 25-41.

Lundberg, K., (2014) Det här är inte mitt land (In Swedish) Stockholm: Atlas.

Mason, P. (2015) PostCapitalism - A Guide to Our Future Allen Lane.

McRobbie, K. \& Polanyi Levitt, K. (eds.) Karl Polanyi in Vienna: The Contemporary Significance of the Great Transformation, Black Rose Books.

Orhangazi, Ö. (2008) 'Financialisation and capital accumulation in the non-financial corporate sector - A theoretical and empirical investigation on the US economy 1973-2003' Cambridge Journal of Economics 32: pp. 863-886.

Polanyi, K., Arensberg, C.M., and Pearson, HW. (eds.) (1957) Trade and Market in the Early Empires - Economies in History and Theory Illinois: The Free Press.

Polanyi, K., (1944) The Great Transformation, Boston: Beacon Press.

Polanyi K. (1933) (translated to English) in McRobbie \& Polanyi Levitt (eds.) (1999), Ch. 31 pp. 347-358.

Rothstein, B. \& Trägårdh, L. in Trägårdh (Ed.) (2007) Ch. 8.

Ryner, M., (2010) 'An Obituary for the Third Way - The Financial Crisis, Transatlantic Political Economy and the Absence of a Social Democratic Alternative', Paper at the $17^{\text {th }}$ International Conference of the Council of European Studies (Shortened version in The Political Quarterly 81 (4) pp. 554-63). 
- (2004) 'Neoliberalizationof Social Democracy - The Swedish Case', Comparative European Politics 2 (1), pp. 97-119.

- (1999) 'Neoliberal Globalization and the Crisis of. Swedish Social Democracy', Economic \& Industrial Democracy SAGE, London Vol. 20 pp. $39-79$.

Sandberg, Å. (ed.) (2013) Nordic Lights - Work, Management and Welfare in Scandinavia, Stockholm, SNS Förlag.

- (1998) 'Good work and productivity' Economic \& Industrial Democracy SAGE, London Vol. 19, no 1, pp. 5-16.

SNF 2016, '̈̈godela: Köp mindre - få tillgång till mer', (in English ₹ 'OwnShare - Buy less, get access to more', Stockholm: Svenska Naturskyddsföreningen (SNF).

Stenfors, A. (2014) - see FESSUD on Sweden (2014).

Trägårdh, L., (ed.) (2007), State and Civil Society in Northern Europe - The Swedish Model Reconsidered. Oxford: Berghahn Books.

Werne, K. and Unsgaard, O. F. ed. (2014) Den stora ovandlingen - En granskning av välfärdsmarknaden Stockholm: Leopard.

Östberg, K. (2012) 'Swedish Social Democracy after the Cold War', in Schmidt, I. and Evans, B. (ed.) Social democracy after the cold war. Athabasca University Press. 